Article

\title{
Estimating Real-Time Water Area of Dongting Lake Using Water Level Information
}

\author{
Yuannan Long ${ }^{1,2}$, Rong Tang ${ }^{2}$, Changshan $\mathrm{Wu}^{2,3, *(1)}$, Changbo Jiang ${ }^{1,2}$ and Shixiong $\mathrm{Hu}^{1,2}$ \\ 1 School of Hydraulic Engineering, Changsha University of Science \& Technology, Changsha 410114, China; \\ lynzhb@csust.edu.cn (Y.L.); jiangchb@csust.edu.cn (C.J.); shu@esu.edu (S.H.) \\ 2 Key Laboratory of Dongting Lake Aquatic Eco-Environmental Control and Restoration of Hunan Province, \\ Changsha 410114, China; tr_try@163.com \\ 3 Department of Geography, University of Wisconsin-Milwaukee, Milwaukee, WI 53211, USA \\ * Correspondence: cswu@uwm.edu; Tel.: +1-414-229-4860
}

Received: 14 May 2019; Accepted: 9 June 2019; Published: 13 June 2019

check for updates

\begin{abstract}
Dongting Lake, the second largest freshwater lake in China, is an important water source for the Yangtze River Basin. The water area of Dongting Lake fluctuates significantly daily, which may cause flooding and other relevant disasters. Although remote sensing techniques may provide lake area estimates with reasonable accuracy, they are not available in real-time and may be susceptible to weather conditions. To address this issue, this paper attempted to examine the relationship between lake area and the water levels at the hydrological stations. Multi-temporal water area data were derived through analyzing Moderate Resolution Imaging Spectroradiometer (MODIS) imagery using the Automatic Water Extraction Index (AWEI). Then we analyzed the inter- and intra-annual variations in the water area of the Dongting Lake. Corresponding water level information at hydrological stations of the Dongting Lake were obtained. Simple linear regression (SLR) models and stepwise multiple linear regression (SMLR) models were constructed using water levels and water level differences from the upstream and downstream hydrological stations. We used the data from 2004 to 2012 and 2012, respectively, to build the model, and applied the data from 2013 to 2015 to evaluate the models. Results suggest that the maximum water area of the Dongting Lake during 2000-2015 has a clear decreasing trend. The variations in the water area were characterized by hydrological seasons, with the annual minimum and maximum water areas occurring in January and September, respectively. The water level at the Chengjingji station, and water level differences between upstream stations and the Chengjingji station, play a major role in estimating the water area. Further, results also show that the SMLR established in 2012 performs the best in estimating water area of the Dongting Lake, especially with high water levels.
\end{abstract}

Keywords: Dongting Lake; water area; water level difference; stepwise multiple linear regression; MODIS

\section{Introduction}

Although lakes only account for a small part of the earth's total water bodies, they are directly associated with climatic changes and human activities, and significantly affect our daily lives [1]. Lake area changes are of great significance to the lake's water ecological environment and water balance [2,3]. The water area of lakes has mostly decreased in recent decades [4,5]. For example, when compared to that in the 1960s, the water area of Lake Chad in the 1970s to 1980s was reduced by 90\% [6]. By analyzing satellite observation data of Siberia since 1973, Smith and Sheng (2005) found that the water areas of Arctic lakes significantly decreased due to global warming [7]. Similarly, major lakes in China, including Poyang Lake, Dongting Lake, Tai Lake, and Hong Lake, have been shrinking 
recently, largely associated with rapid urbanization [8,9]. The shrinking of the lake area is mainly affected by two factors: First, the amount of water entering the lake is reduced due to the influence of climate change and water conservancy engineering regulation [10], and second, humans have invaded the original lake wetlands and flood storage areas (e.g., urbanization) [9]. Lake area dynamics may result in frequent natural disasters such as droughts and floods. The shrinking of lake area will lead to the reduction of lake capacity [11]. During the flood period, flooding is more likely to occur under the same inflow conditions. In the dry season, the water volume is reduced and drought disasters are more likely to occur. For example, Huang (2011) showed that the severe shrinkage of Dongting Lake resulted in the deterioration of its flood diversion and storage capacity, and led to more frequent flood disasters [12]. In addition to long-term changes, short-term (e.g., daily) lake area variations are of more significance as they may cause disasters such as flooding or drought $[7,13,14]$. Taking Dongting Lake as an example, significant changes in lake areas exist, ranging from $1572.59 \mathrm{~km}^{2}$ during the rainy season to $809.75 \mathrm{~km}^{2}$ during the dry season [13].

Due to the importance of daily lake area information, a number of methods, including field measurement, topographic analysis, hydrodynamic modeling, and remote sensing techniques, have been developed recently. For example, based on the measured topographic data of Poyang Lake, Li (2014) established a hydrodynamic model to simulate the water surface area of Poyang Lake, and the results show that the modeled lake area is in reasonably good agreement with the one obtained from remote sensing imagery [15]. Although with relatively high accuracy, the first three methods are labor intensive and costly. In the meantime, with large geographic coverages, repeated observation ability, and long-time spans, remote sensing techniques are considered effective methods for monitoring water area of large lakes [12,16]. For example, Feng (2012) evaluated inundation changes of Poyang Lake between 2000 and 2010 using Moderate Resolution Imaging Spectroradiometer (MODIS) imagery [17]. Plug et al. [18] examined the changes of Tundra Lake between 1978 and 2001 in Northwest Canada through using six Landsat Thematic Mapper (TM) images [18].

Although with some success, remote sensing techniques are with shortcomings [19]. Remote sensing monitoring is susceptible to weather conditions, as optical remote sensing cannot detect a lakes' extent due to cloud coverage associated with severe weather conditions (e.g., storms). Moreover, remotely sensed satellite imagery cannot be obtained daily, as most satellites have a re-visit cycle of several days. For example, Landsat has a revisit cycle of 16 days. On the contrary, water level information can be obtained in real-time at each monitoring station, which could help to estimate real-time lake areas accurately. Therefore, an estimate of real-time lake area may be available if the relationship between water area and measured water level data can be constructed. Water level is a measure of the change in lake water storage, which is the most basic element to measure the hydrological status of lakes. Temporal and spatial changes in water level are not only affected by natural factors such as climate, hydrology, and landform, but also have a close relationship with the increasing human activities in recent years [20-22]. To reach this goal, Ding et al. [23] and Du et al. [24] have established the relationship between lake water area and measured water level at the Chenglingii station (exit of the lake) of Dongting Lake, China [23,24]. In fact, the water level upstream of the lake also affects the lake water area. Especially for large lakes, the water levels at different locations are not at the same horizontal plane, and there may exist a large water level difference between the upstream and downstream areas. Therefore, the water level of a single site may not accurately represent the water area, and such a simple correlation analysis may introduce significant errors. Therefore, it is necessary to establish a water level-water area model considering the water level difference between the upstream and the downstream areas by combining a long series of multi-source remote sensing data.

The objective of this paper, therefore, is to construct a relationship between water area and real-time water level measures, as well as water level differences, obtained from hydrological stations. Taking Dongting Lake, China, as an example, this paper attempts to estimate lake areas from real-time water level measures. For generating multi-temporal areal estimates of Dongting Lake, we applied the thresholding technique applied to an Automatic Water Extraction Index (AWEI) derived from MODIS 
and Landsat Thematic Mapper (TM) imagery of the Dongting Lake region from 2000 to 2015. Moreover, real-time water levels and water level differences at the hydrological stations of the Dongting Lake's three estuaries and four incoming rivers, and from the Chenglingji station, were obtained. Finally, the quantitative relationship between the lake area and water levels was constructed using regression analysis techniques.

\section{Study Area and Data Source}

\subsection{Study Area}

Dongting Lake (Figure 1) is located on the southern bank of Yangtze River, China, with a complex water system. It receives water from four rivers (Xiang River, Zi River, Yuan River, and Li River) and three estuaries (Songzi River, Hudu River, and Ouchi River), and flows into the Yangtze River at the Chenglingji station. Dongting Lake has a wide areal coverage and numerous hydrological stations. We chose hydrological stations with water level data under the condition of having a perennial water surface. Six hydrological stations, namely Zhouwenmiao station, Nanzui station, Xiaohezui station, Yangliutan station, Yingtian station, and the Chenglingji station (at the exit of the lake), met this requirement. Figure 1 shows the geographical locations of Dongting Lake, the major river systems, and the hydrological stations.

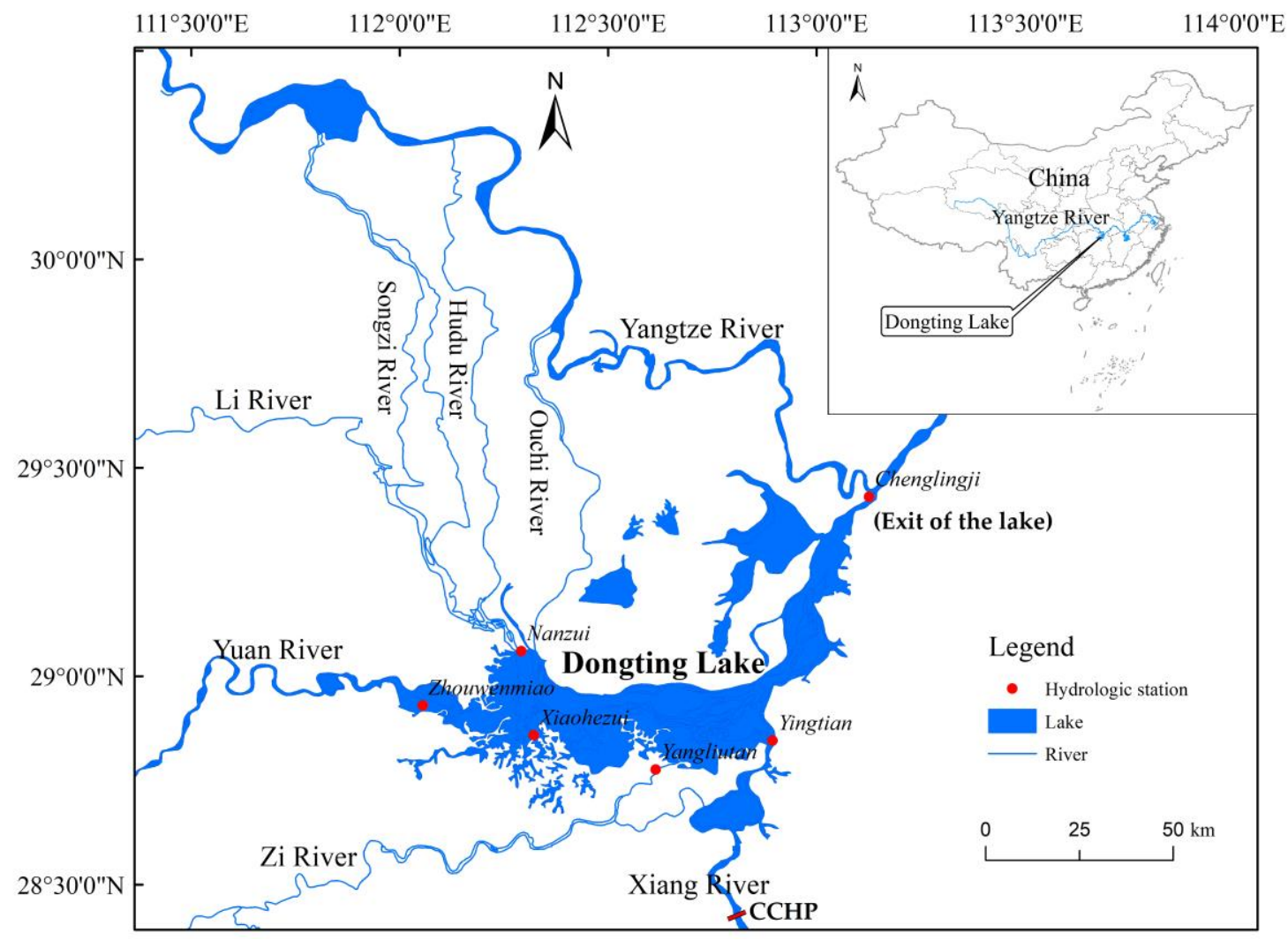

Figure 1. Location of Dongting Lake and the distribution of hydrological stations.

\subsection{Data Source}

Terra Moderate Resolution Imaging Spectroradiometer (MODIS) L2B data were widely employed for lake area monitoring due to its repeated observation ability, long-time spans, high spectral resolutions, and free data availability [12].In this research, MODIS data were obtained from the National Aeronautics and Space Administration (NASA) website (http://ladsweb.nascom.nasa.gov/), and Landsat imageries with high spatial resolution were obtained from the geospatial data cloud website (http://www.gscloud.cn/). The Terra/MODIS L2B data used in this study included MOD09_GA 
and MOD09_GQ (where MOD09_GA has a spatial resolution of $500 \mathrm{~m}$, and MOD09_GQ has a spatial resolution of $250 \mathrm{~m}$ ). In addition to MODIS imagery, Landsat 4-5 Thematic Mapper (TM) and Landsat 8 Operational Land Imager (OLI) (with a resolution of $30 \mathrm{~m}$ ) were selected. Landsat 4-5 TM imagery has six spectral bands in the visible and infrared wavelength with a spatial resolution of $30 \mathrm{~m}$, and one thermal infrared band with a resolution of $120 \mathrm{~m}$. Landsat $4-5$ is with a repeat cycle of 16 days. Landsat 8 OLI, launched in 2013, is with seven visible near-infrared spectral bands (e.g., coastal, blue, green, red, near infrared, short-wave infrared 1, and short-wave infrared 2). Landsat 4-5 TM and Landsat 8 imagery has been widely applied in water resource applications. The row and column numbers of the study area were $(124,40),(124,41)$, and $(123,41)$. A total of 240 scenes of MODIS data and 7 scenes of Landsat data acquired from 2000 to 2015 were used. The sampling dates of Landsat images were 11 November 2006, 8 December 2008, 15 April 2009, 21 July 2011, 1 August 2013, 7 October 2014, and 25 October 2015, respectively.

In addition to remote sensing imagery, water levels were measured at the stations of the three estuaries and four incoming rivers (2000-2015). The sampling rate of the hydrological stations is once a day in the dry season, and the sampling time is 08:00 every day. The sampling rate is once an hour during the flood season, and especially in the case of the over-warning level, the sampling frequency can be up to 15 minutes. The water level measured by the hydrological station at 08:00 is used in this paper. These water level data, with the Wusong elevation datum, were provided by the Hydrology Bureau of the Yangtze River Water Resources Commission and the Hydrology and Water Resources Survey Bureau of Hunan Province. Table 1 shows the hydrological station information of Dongting Lake.

Table 1. Hydrological station information of Dongting Lake.

\begin{tabular}{lccc}
\hline \multicolumn{2}{c}{ Hydrological Stations } & Location & $\begin{array}{c}\text { Annual Mean Water } \\
\text { Level in 2012 }\end{array}$ \\
\hline Downstream (exit of the lake) & Chenglingji station & $\left(29^{\circ} 25^{\prime} \mathrm{N}, 113^{\circ} 08^{\prime} \mathrm{E}\right)$ & $25.97 \mathrm{~m}$ \\
& Zhouwenmiao station & $\left(28^{\circ} 55^{\prime} \mathrm{N}, 112^{\circ} 03^{\prime} \mathrm{E}\right)$ & $30.64 \mathrm{~m}$ \\
& Nanzui station & $\left(29^{\circ} 4^{\prime} \mathrm{N}, 112^{\circ} 17^{\prime} \mathrm{E}\right)$ & $30.09 \mathrm{~m}$ \\
Upstream & Xiaohezui station & $\left(28^{\circ} 51^{\prime} \mathrm{N}, 112^{\circ} 19^{\prime} \mathrm{E}\right)$ & $29.99 \mathrm{~m}$ \\
& Yangliutan station & $\left(28^{\circ} 47^{\prime} \mathrm{N}, 112^{\circ} 37^{\prime} \mathrm{E}\right)$ & $29.23 \mathrm{~m}$ \\
& Yingtian station & $\left(28^{\circ} 50^{\prime} \mathrm{N}, 112^{\circ} 54^{\prime} \mathrm{E}\right)$ & $26.80 \mathrm{~m}$ \\
\hline
\end{tabular}

\section{Methods}

\subsection{Water Area Extraction and Evaluation}

Based on MODIS and Landsat images, the water body index method was used to extract the lake boundaries, and the boundaries obtained by the two methods were compared to evaluate the accuracy of MODIS data extraction.

\subsubsection{Water Area Extraction}

For extracting water area of the Dongting Lake, the AWEI developed by Feyisa et al. (2014) was employed [16]. AWEI is proposed as an alternative and improved water index and can enhance the separation of water from dark surfaces and other non-aqueous bodies (Feyisa et al. 2014). Based on whether the shadow in the region is the main interference object, $A W E I_{n s h}$ (no shadow interference) and $A W E I_{s h}$ (with shadow interference) are defined as follows:

$$
\begin{aligned}
& A W E I_{\text {nSh }}=4 \times\left(R_{G}-R_{S W I R 1}\right)-0.25 \times R_{N I R}+2.75 \times R_{S W I R 2}, \text { and } \\
& A W E I_{\text {Sh }}=R_{B}+2.5 \times R_{G}-1.5 \times\left(R_{N I R}+R_{S W I R 1}\right)-0.25 \times R_{S W I R 2}
\end{aligned}
$$

where $R_{B}, R_{G}, R_{N I R}, R_{S W I R 1}$, and $R_{S W I R 2}$ are the reflectance of the blue band, green band, near infrared, short-wave infrared band 1 , and short-wave infrared band 2. For MODIS imagery, $R_{B}, R_{G}, R_{N I R}$, 
$R_{\text {SWIR1 }}$, and $R_{S W I R 2}$ correspond to the reflectance of bands 3, 4, 2, 6, and 7, while for Landsat TM, and OLI imagery, $R_{B}, R_{G}, R_{N I R}, R_{S W I R 1}$, and $R_{S W I R 2}$ correspond to the reflectance of bands $1,2,4$, 5, and 7. In this paper, $A W E I_{s h}$ was employed to extract the water body from MODIS images due to the existence of shadows. For accurate water area extraction in the Dongting Lake area, MODIS L2B remote sensing images with $250 \mathrm{~m}$ resolution were employed. The downloaded MODIS data were processed using the MODIS Reprojection Tool (MRT) software. First, the MOD09_GAbands b1 and b2 and MOD09_GQ bands b1-b7 were selected for water area extraction. Then all the images were converted to the Universal Transverse Mercator (UTM) projection. To be consistent with the MOD09_GQ, the $500 \mathrm{~m}$ spatial resolution bands of MOD09_GA were resampled to $250 \mathrm{~m}$ using the ENVI 5.3 Resize data tool (Exelis Inc., Tysons Corner, VA, USA), and combined with MOD09_GQ bands using the Layer Stacking tool.

Two hundred and forty (240) MODIS images of the Dongting Lake from 2000 to 2015 were selected. The water surface area of the lake was extracted by the $A W E I_{s h}$-thresholding method to analyze its temporal and spatial variations. First, the $A W E I_{s h}$ of the obtained study area images was calculated using Equation (2). Then, an appropriate threshold was set through visually analyzing the relationship between the AWEI values and water body boundaries of the MODIS imagery. To obtain an accurate area, post-processing was also performed using the ArcGIS software developed by the Environmental Systems Research Institute (ESRI).

\subsubsection{Accuracy Assessment of Water Area Extraction}

To ensure the accuracy of the water area extraction results from MODIS imagery, the Landsat data in the same period were used for accuracy assessment. Assuming that the water area extracted by Landsat is the "true" value, the relative error $(R e)$ was introduced to quantitatively investigate the degree of coincidence between MODIS data and Landsat data:

$$
R e=\frac{\mid \text { Area }_{\text {MODIS }}-\text { Area }_{\text {Landsat }} \mid}{\text { Area }_{\text {Landsat }}} \times 100 \%,
$$

where Area $_{\text {MODIS }}$ and Area $_{\text {Landsat }}$ are the lake water area obtained from MODIS and Landsat images, respectively.

\subsection{Examining the Relationship between Water Area and Water Level}

The relationship between water area and water level was analyzed by simple linear regression (SLR). The SLR model is used to describe the relationship between one dependent variable and a single independent variable. The general form of SLR model is given by

$$
A=\alpha+\beta H+\varepsilon,
$$

where $A$ is the water area of Dongting Lake extracted using remote sensing imagery, $H$ is the water level at the hydrological station located at the exit of the Dongting Lake (e.g., Chenglingji station), $\alpha$ and $\beta$ are the regression coefficients, and $\varepsilon$ is the error. The independent variable is tested for significance through an $F$ test. According to the least square criterion, the regression coefficient is estimated by minimizing the sum of squared vertical deviations from each data point to the best fitting line.

In addition to the SLR, we also developed multiple linear regression (MLR), which included not only the water level at the exit of the Dongting Lake (the Chenglingji station), but also the water level differences from upstream stations and the exit of the Dongting Lake. The general form of the MLR model is given by

$$
A=\alpha+\beta H+\sum \gamma_{i} \Delta H_{i}+\varepsilon,
$$

where, $A$ represents the water area of Dongting Lake, $H$ is the water level at the exit of the Dongting Lake, $\Delta H_{i}$ is the water level difference between the station located at the exit of the Dongting Lake and 
upstream station $i$, and $\varepsilon$ is the error. Considering that the Chenglingji station is located at the exit of Dongting Lake, and five stations, including Zhouwenmiao, Nanzui, Xiaohezui, Yangliutan, and Yingtian are located upstream, $H$ is the water level of the Chenglingii station and $\Delta H_{i}$ is the water level differences between the Chenglingji station and the five (5) upstream stations. Since the MLR model has multiple independent variables, stepwise regression is considered as an effective approach to select the independent variables [25]. The method is to introduce independent variables one by one. The introduced condition is that the independent variable is significant after an $F$ test. After introducing an independent variable, the selected variables are tested one by one. If the original introduced variable is no longer significant due to the introduction of later variables, it will be removed. The introduction of a variable or the elimination of a variable from the regression equation is a step of stepwise regression, and an $F$ test should be conducted for each step to ensure that only significant variables are included in the regression equation before the introduction of a new variable. This process is repeated until no insignificant independent variables are selected into the regression equation and no significant independent variables are removed from the regression equation. In this way, the independent variables used in the stepwise multiple linear regression (SMLR) model are of statistical significance.

Considering the Three Gorges Reservoir was built in 2003, we set up SLR and SMLR models in 2004-2012. At the same time, the water area and water level changes greatly, therefore, we used the latest year data with more available remote sensing images (2012) to establish SLR and SMLR models.

\section{Results}

\subsection{Water Area Extraction of Dongting Lake}

The water area was extracted through applying the AWEI to the MODIS images, and validated using the Landsat images acquired during the same day. As an example, Figure 2 shows the water-land boundaries of the Dongting Lake using both MODIS and Landsat imagery acquired on 13 August 2006. Through visualizing Figure 2, we can find that small river networks have been mis-specified using MODIS imagery, especially during low-flow periods. This is reasonable due to the coarse resolution $(250 \mathrm{~m})$ of the MODIS imagery. Landsat imagery could provide much better details, but with significantly lower temporal frequency. Therefore, for this study, Landsat imagery was applied for validation. Table 2 shows lake water area obtained from MODIS and Landsat images, and the Re values. It can be seen that $R e$ values are less than $10 \%$, indicating that the MODIS data and the Landsat data were in good agreement and satisfied the requirements for accurate extraction of the Dongting Lake area. Therefore, it is reasonable to record and study the short- and long-term changes of Dongting Lake water using the medium-resolution MODIS time series data and the AWEI threshold method.

Table 2. Dongting Lake water area obtained from Moderate Resolution Imaging Spectroradiometer (MODIS) and Landsat images.

\begin{tabular}{cccccccc}
\hline Data. & $13 / 8 / 2006$ & $8 / 12 / 2008$ & $15 / 4 / 2009$ & $21 / 7 / 2011$ & $1 / 8 / 2013$ & $7 / 10 / 2014$ & $25 / 10 / 2015$ \\
\hline Area $_{\text {Landsat }}\left(\mathbf{k m}^{\mathbf{2}}\right)$ & 1088 & 735 & 1037 & 1112 & 1049 & 632 & 804 \\
Area $_{\text {MODIS }}\left(\mathbf{k m}^{\mathbf{2}}\right)$ & 1138 & 776 & 1114 & 1011 & 1123 & 665 & 881 \\
$\operatorname{Re}(\mathbf{\%})$ & 4.63 & 5.59 & 7.37 & 9.15 & 7.12 & 5.10 & 9.52 \\
\hline
\end{tabular}



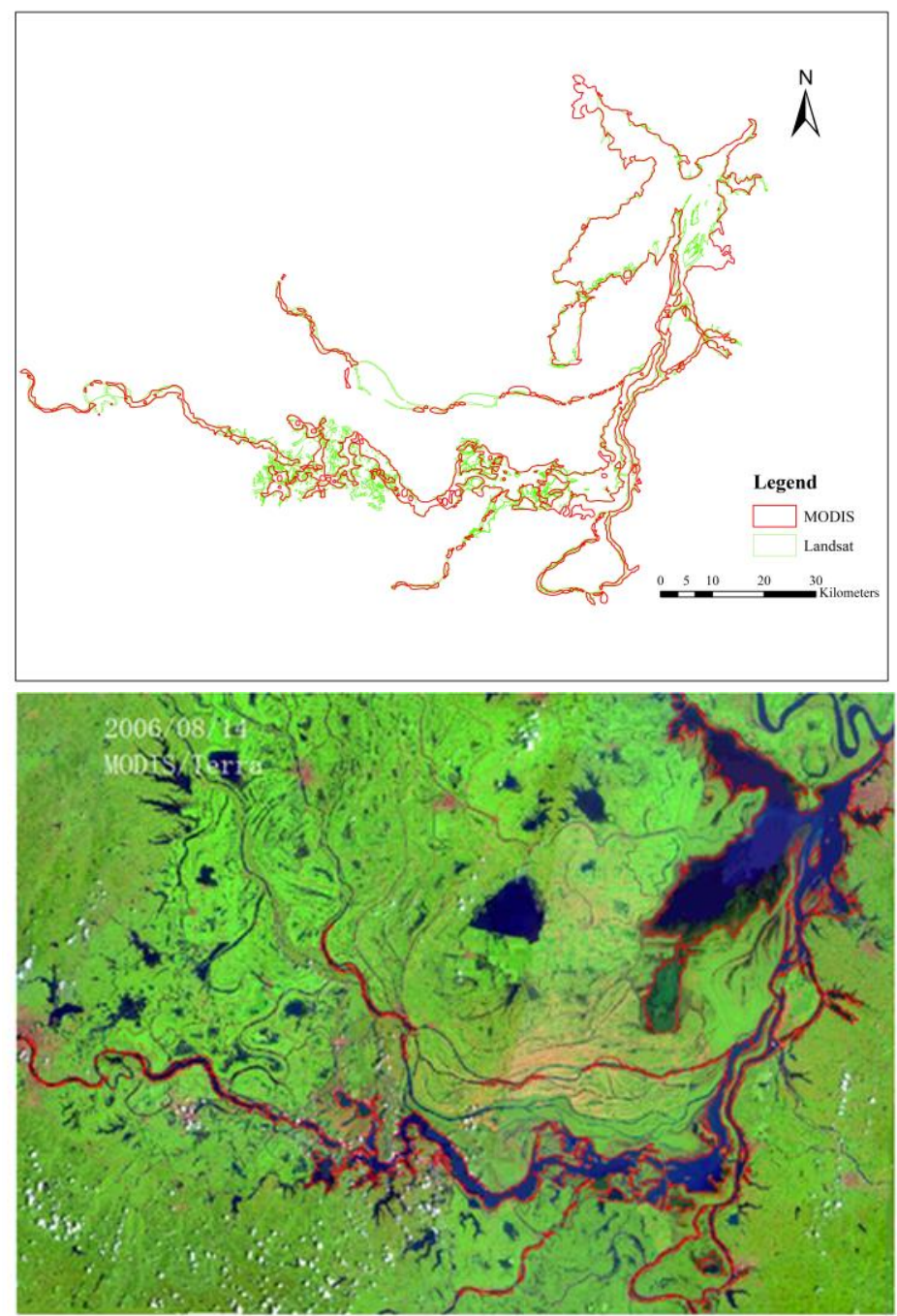

Figure 2. Comparison of water area boundary extracted by MODIS and Landsat in the same period.

Through applying the MODIS imagery obtained from 2000 to 2015, we obtained multi-temporal areas of the Dongting Lake. As shown in Figures 3 and 4, we found that the area changes of the Dongting Lake fluctuated greatly from 2000 to 2015. The maximum water area during the year generally occurred during July and September. The minimum water area value during the year generally occurred from January to March and from October to December, which was largely consistent with the distribution pattern of the water levels during the year. Figure 3a shows the distribution of the monthly maximum, minimum, and average water area of Dongting Lake from 2000 to 2015. From January to April and in December, the difference between the maximum and minimum values was small. The difference was large from May to October. The minimum intra-annual variation was in January, and the maximum intra-annual variation was in May.

From the perspective of inter-annual variation, the variation in the annual minimum water area showed no clear pattern. However, overall the annual maximum water area showed a decreasing trend. The difference between the annual maximum and annual minimum gradually decreased. The difference between the annual maximum and minimum in 2000-2003 was significantly larger than that in 2004-2011, and the difference in 2012-2015 was smaller than the difference in 2004-2011. Furthermore, this is in line with the changes in the fluctuation of the water level at Chenglingji station. 


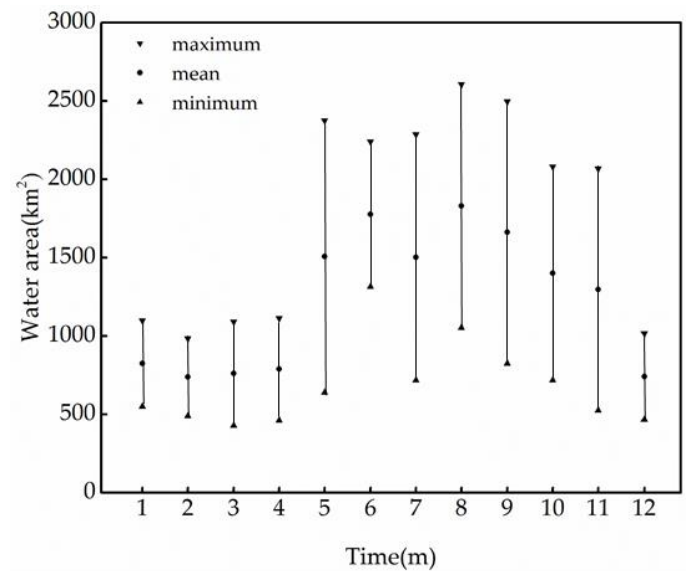

(a)

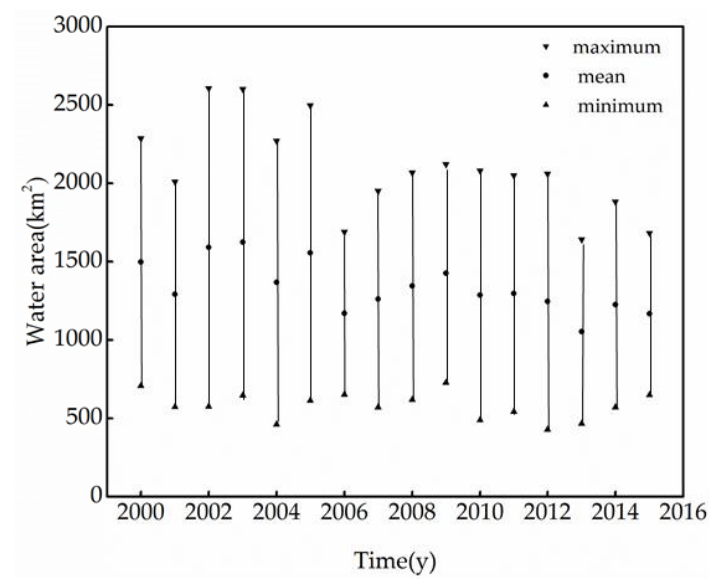

(b)

Figure 3. Trends in the maximum and minimum water area from 2000 to 2015. (a) Monthly changes and (b) annual changes.

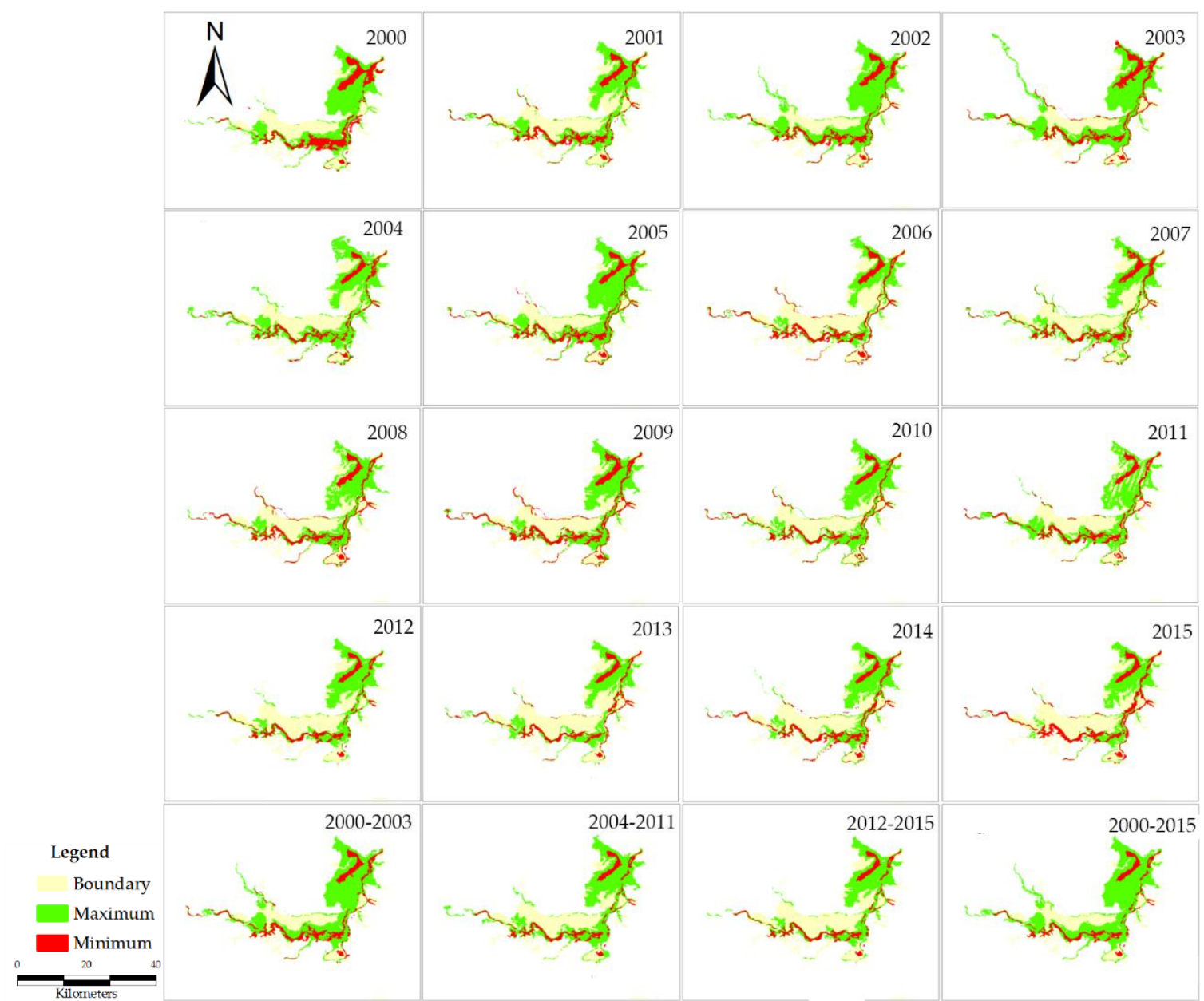

Figure 4. Annual maximum and minimum water area of Dongting Lake in 2000-2015.

\subsection{Water Level Changes of Dongting Lake}

Water level data was obtained from the six stations listed in Table 1. In particular, Chenglingji station is located at the exit of the lake, while the other five stations are at the upstream. From 2000 to 2003, the annual average water level fluctuation at Chenglingji station was small $(0.6 \mathrm{~m})$ before the Three Gorges Reservoir (TGR). After the completion of the TGR over the period from 2004 to 2011, 
the annual average water level fluctuation at Chenglingii station increased significantly, reaching 2.0 m. From 2012-2015, with the completion of the Changsha Comprehensive Hub Project (CCHP), the annual average water level fluctuation at Chenglingji station rose to $2.8 \mathrm{~m}$.

According to the water level at the Chenglingii station from 2009 to 2015, the water level dynamics during the year can be roughly divided into four stages: January to March, April to June, July to September, and October to December, with the average water level levels of $21.58 \mathrm{~m}, 26.21 \mathrm{~m}, 28.77 \mathrm{~m}$, and $22.90 \mathrm{~m}$, respectively. The highest monthly average water level $(30.07 \mathrm{~m})$ at the Chenglingi station appeared in July, and the lowest $(21.26 \mathrm{~m})$ was in January.

There was a large upstream and downstream difference in the water levels of the Dongting Lake area. Figure 5 shows the changes in water level differences (water level at the stations of the lake minus the water level at Chenglingji station). The variation in water level difference was consistent across all stations. The water level difference was relatively small in the high-flow period and relatively large in the low-flow period. Take the Zhouwenmiao station as an example, from January to March, April to June, July to September, and October to December, the water level difference was $7.80 \mathrm{~m}, 5.20 \mathrm{~m}$, $2.39 \mathrm{~m}$, and $6.47 \mathrm{~m}$, respectively. These results are consistent with the changes in the water level across hydrological seasons.

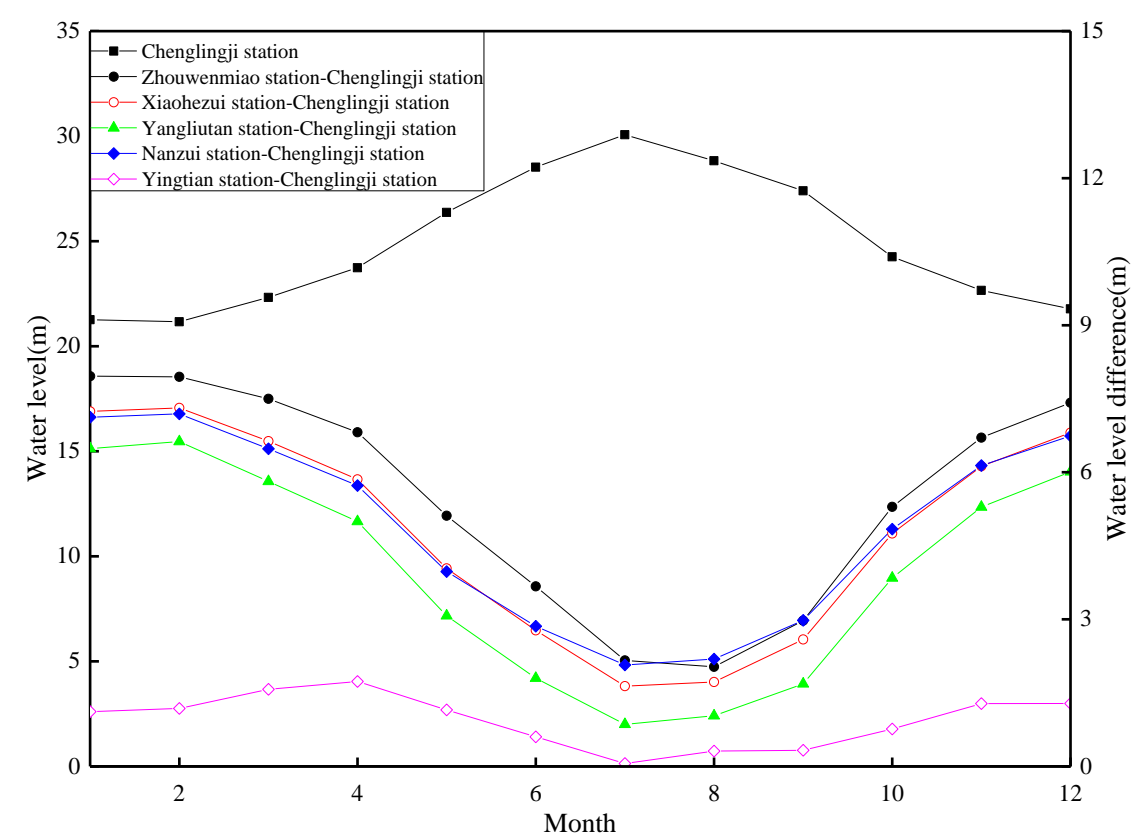

Figure 5. Water level difference between Chenglingji and other hydrological stations.

\subsection{Analysis of the Change in Relationship between Water Area and Water Level of Dongting Lake}

Due to the impact of the TGR built in 2003, the water levels of Dongting Lake have changed significantly. In this research, we only analyzed the data after 2004. Scatter plots of water levels and water areas (Figure 6) indicate that the water level and water area of Chenglingji station tended to be linearly correlated, and the correlation coefficients was greater than those for other stations. The scatter points of water level-water area at the Zhouwenmiao and Yangliutan stations had a high dispersion, with correlation coefficients less than 0.5 .

Two periods, 2004-2012 (with 143 samples) and 2012 only (with 19 samples), were employed for examining the relationship between water area and water level of Dongting Lake. Through applying the SLR (Equation (4)), the results (see Table 3) indicate that the water level at the Chenglingji station plays a significant role in estimating water areas during 2004-2012 (Model $A_{1}$ ) and 2012 only (Model $A_{3}$ ), with correlation coefficients of 0.770 and 0.889 , respectively. The better performance with the 2012-only data may be due to the unchanged terrain after 2012. Most of the terrain changes of the Dongting Lake 
occurred from 2004 to 2012 due to the completion of large-scale water conservancy projects. After 2012, terrain changes can be ignored as no new water conservancy project has been constructed.
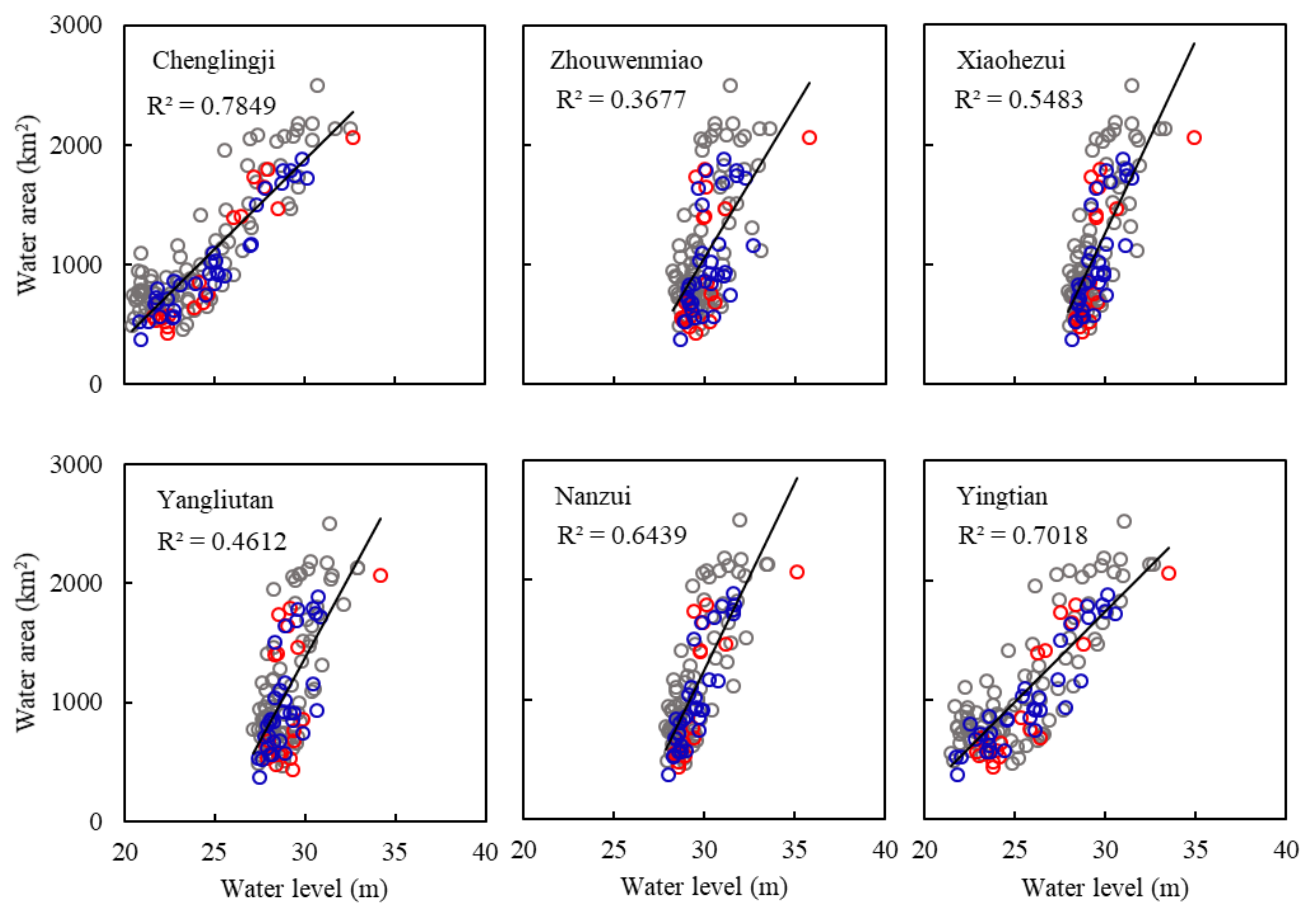

Figure 6. Relation between water area and water level of hydrological stations in 2004-2015.

Table 3. Linear regression models.

\begin{tabular}{cccccc}
\hline Models & $\begin{array}{c}\text { Data } \\
\text { Used }\end{array}$ & Method & Relational Expression & $\begin{array}{c}\mathbf{R}^{2} \text { (Coefficient of } \\
\text { Determination) }\end{array}$ & $p$ Values \\
\hline$A_{1}$ & $2004-2012$ & SLR & $A_{1}=-2557.557+149.014 H$ & 0.770 & 0.00 \\
$A_{2}$ & $2004-2012$ & SMLR & $\begin{array}{c}A_{2}=-2098.530+ \\
136.204 H-138.202 \Delta H_{y t}\end{array}$ & 0.795 & $0.00,0.001$ \\
$A_{3}$ & 2012 & SLR & $A_{3}=-3189.8+168.69 H$ & 0.889 & 0.00 \\
$A_{4}$ & 2012 & SMLR & $A_{4}=-551.528+90.096 H-$ & 0.942 & $0.001,0.002$ \\
\hline
\end{tabular}

${ }^{*} A$ is the water area of Dongting Lake. $H$ is the water level of the Chenglingji station. $\Delta H_{y t}$ is the water level difference between Yingtian station and Chenglingji station. $\Delta H_{z w m}$ is the water level difference between Zhouwenmiao station and Chenglingji station.

Although water level at the Chenglingji station plays an essential role in estimating the area of the Dongting Lake, such a single measure may not adequately represent the complex water exchange between rivers and lakes in such a large lake. As a result, the relationship between the lake water area and water levels in different hydrological seasons is different. In addition, the water level difference may be an important factor affecting the change in the water area of the Dongting Lake. Therefore, through applying the SMLR models (Equation (5)), this paper comprehensively investigated the relationship among the water area, the water level at Chenglingji, and the water level difference between the Chenglingji station and five upstream stations (Zhouwenmiao, Xiaohezui, Yangliutan, Nanzui, and Yingtian). Results (see Table 3) suggest that the addition of water level differences between upstream stations and the Chenglingji station improves the model performance. With the 2004-2012 data, the model $\left(A_{2}\right)$ includes the water level difference between Yingtian station and Chenglingji station, and the coefficient of determination increases from 0.770 to 0.795 . Similarly, with the 2012-only data, the model $\left(A_{4}\right)$ includes the water level difference between Zhouwenmiao station and Chenglingji station, and the coefficient of determination increases from 0.889 to 0.942 . 
Further, we applied these models $\left(A_{1}, A_{2}, A_{3}\right.$ and $\left.A_{4}\right)$ to predict the water area of the Dongting Lake from 2013 to 2015 (with 34 samples). The measured water area data were extracted from remote sensing images, and the water level information was measured at the respective hydrological stations. As shown in Figure 7, all of the models provided satisfactory performance in predicting water areas of the Dongting Lake. Table 4 shows the performance statistics of these modes. According to the $\mathrm{R}^{2}$, RMSE (Root Mean-square Error), and NSE (Nash-Sutcliffe efficiency), the accuracy of $A_{1}$ and $A_{2}$ is lower than that of $A_{3}$ and $A_{4}$. This may be due to the fact that the water level and water area of the Dongting Lake have changed significantly in the past ten years (related to the construction of the Water Conservancy Project and terrain changes of Dongting Lake). Therefore, it is difficult to accurately predict the current lake area using the previous data. In contrast, the accuracy of lake area prediction using the most recent years (e.g., 2012) has been greatly improved.
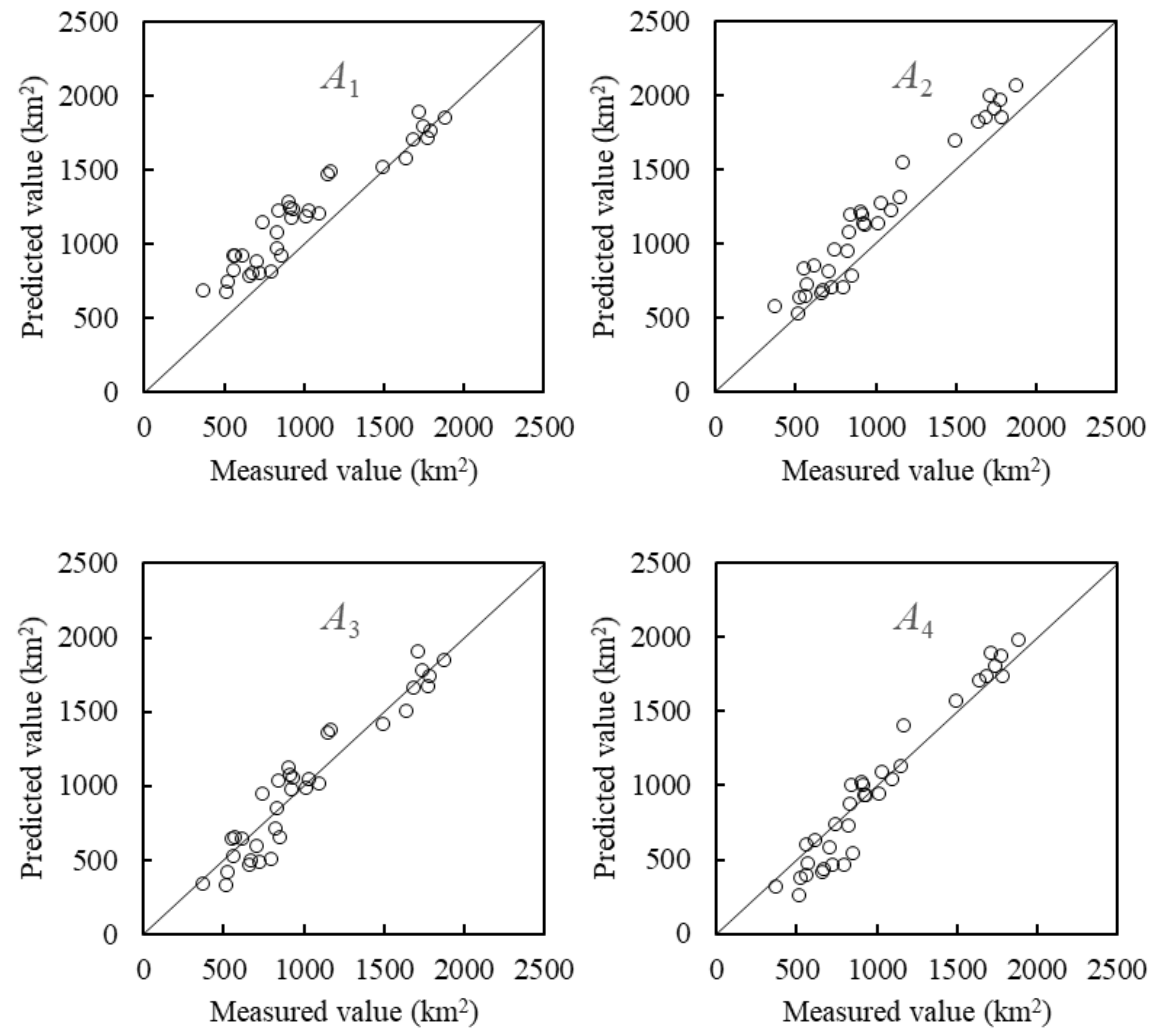

Figure 7. Comparison between the predicted and measured value of water area.

Table 4. Performance comparison of $A_{1}, A_{2}, A_{3}$, and $A_{4}$ models.

\begin{tabular}{cccc}
\hline Models & $\begin{array}{c}\mathbf{R}^{\mathbf{2}} \text { (Coefficient of } \\
\text { Determination) }\end{array}$ & $\begin{array}{c}\text { RMSE (Root } \\
\text { Mean-Square Error) }\end{array}$ & $\begin{array}{c}\text { NSE (Nash-Sutcliffe } \\
\text { Efficiency) }\end{array}$ \\
\hline$A_{1}$ & 0.9116 & 224.93 & 0.62 \\
$A_{2}$ & 0.9459 & 189.86 & 0.84 \\
$A_{3}$ & 0.9116 & 142.64 & 0.91 \\
$A_{4}$ & 0.9461 & 148.59 & 0.92 \\
\hline
\end{tabular}

Analysis of results also suggests that $A_{3}$ and $A_{4}$ have similar accuracy in predicting water area from 2013 to 2015. It should be noted that we are more concerned with the surface area at high water levels. Flood disaster occurs at high water levels, and the water surface area of the Dongting Lake during floods is essential. Therefore, we selected the measured and predicted values when the water level in the Chenglingji station was greater than $25 \mathrm{~m}$ from 2013-2015. Table 5 shows the performance statistics of candidate models to judge the forecasting abilities. As we can see, both $A_{3}$ and $A_{4}$ provided satisfactory performance in predicting water area when the water level is high, although the $A_{4}$ model 
is more accurate. Through the SMLR model, we can accurately estimate the surface area of the lake, especially when the water level is high.

Table 5. Performance comparison of $A_{3}$ and $A_{4}$ models when the water level is greater than $25 \mathrm{~m}$.

\begin{tabular}{cccc}
\hline Models & $\begin{array}{c}\mathbf{R}^{\mathbf{2}} \text { (Coefficient of } \\
\text { Determination) }\end{array}$ & $\begin{array}{c}\text { RMSE (Root } \\
\text { Mean-Square Error) }\end{array}$ & $\begin{array}{c}\text { NSE (Nash-Sutcliffe } \\
\text { Efficiency) }\end{array}$ \\
\hline$A_{3}$ & 0.9255 & 140.052 & 0.81 \\
$A_{4}$ & 0.9673 & 102.779 & 0.94 \\
\hline
\end{tabular}

\section{Conclusions}

Real-time water area monitoring is essential for the Dongting Lake as the dynamics of lake water area may lead to natural disasters, such as floods or droughts. In this paper, the AWEIsh-supervised classification method was used to interpret the 240 scenes of MODIS images from 2000 to 2015, and the water area of Dongting Lake was extracted, and the water area variations were comprehensively analyzed. Combined with the water level data of the same period, SLR and SMLR regression analysis models were constructed to estimate real-time water area of the Dongting Lake. Analyses of results suggest four major conclusions:

1. From 2000 to 2015, the annual maximum water area showed a decreasing trend and the annual minimum water area showed no clear pattern. The intra-annual water area variation of Dongting Lake has hydrological seasonal characteristics. The maximum water area value occurred from July to September. The minimum water area value during the year generally occurred from January to March and from October to December, which was largely consistent with the distribution pattern of the water level during the year;

2. From 2000 to 2015, the annual average water level fluctuation at Chenglingji station increased significantly. There is a large upstream and downstream difference in the water level of the Dongting Lake. The water level difference was relatively small in the high-flow period and relatively large in the low-flow period;

3. Water level at the exit of the Dongting Lake (e.g., Chengingji station) plays a major role in estimating the water area, and differences of water levels from upstream stations and the exit of the Dongting Lake are also essential as the modeling performance has significantly improved with the inclusion of the water level differences; and

4. The models with 2004-2012 data and 2012-only data showed remarkable differences in modeling performance, with the 2012-only data performing significantly better, and the established models performing better with higher water levels.

Author Contributions: Y.L., R.T. and C.W. analyzed the data and wrote the manuscript, and C.J. and S.H. designed the modeling approach.

Funding: This research was funded by the National Natural Science Foundation of China (51809020 and 51839002), the Natural Science Foundation of Hunan Province, China (2016JJ3011, 2018JJ3535 and 2016WK2017), and the Hydraulic Engineering Science and Technology Project of Hunan Province, China (201513-37).

Acknowledgments: The authors appreciate anonymous reviewers whose comments have substantially improved the manuscript.

Conflicts of Interest: The authors declare no conflict of interest.

\section{References}

1. Ma, B.; Wu, L.; Zhang, X.; Li, X.; Liu, Y.; Wang, S. Locally adaptive unmixing method for lake-water area extraction based on MODIS $250 \mathrm{~m}$ bands. Int. J. Appl. Earth Obs. Geoinf. 2014, 33, 109-118. [CrossRef]

2. Lee, H.; Durand, M.; Jung, H.C.; Alsdorf, D.; Shum, C.K.; Sheng, Y. Characterization of surface water storage changes in Arctic lakes using simulated SWOT measurements. Int. J. Remote Sens. 2010, 31, 3931-3953. [CrossRef] 
3. Singh, A.; Seitz, F.; Schwatke, C. Inter-annual water storage changes in the Aral Sea from multi-mission satellite altimetry, optical remote sensing, and GRACE satellite gravimetry. Remote Sens. Environ. 2012, 123, 187-195. [CrossRef]

4. Shang, S.; Shang, S. Simplified Lake Surface Area Method for the Minimum Ecological Water Level of Lakes and Wetlands. Water 2018, 10, 1056. [CrossRef]

5. Micklin, P.; Aladin, N.V. Reclaiming the Aral Sea. Sci. Am. 2008, 298, 64-71. [CrossRef] [PubMed]

6. Policelli, F.; Hubbard, A.; Jung, H.; Zaitchik, B.; Ichoku, C. Lake chad total surface water area as derived from land surface temperature and radar remote sensing data. Remote Sens. 2018, 10, 252. [CrossRef]

7. Smith, L.C.; Sheng, Y.; Macdonald, G.M. Disappearing Arctic Lakes. Science 2005, 308, 1429. [CrossRef]

8. Zhang, G.X.; Yin, X.Y.; Feng, X.Q. Review of the Issues Related to Wetland Hydrology Research. Wetl. Sci. 2008, 6, 105-115.

9. Du, Y.; Xue, H.P.; Wu, S.J.; Ling, F.; Xiao, F.; Wei, X.H. Lake area changes in the middle Yangtze region of China over the 20th century. J. Environ. Manag. 2011, 92, 1248-1255. [CrossRef]

10. Bai, J.; Chen, X.; Yang, L.; Fang, H. Monitoring variations of inland lakes in the arid region of Central Asia. Front. Earth Sci. 2012, 6, 147-156. [CrossRef]

11. Nakayama, T.; Watanabe, M. Role of flood storage ability of lakes in the Changjiang River catchment. Glob. Planet. Chang. 2008, 63, 9-22. [CrossRef]

12. Huang, S.; Li, J.; Xu, M. Water surface variations monitoring and flood hazard analysis in Dongting Lake area using long-term Terra/MODIS data time series. Nat. Hazards 2012, 62, 93-100. [CrossRef]

13. Xing, L.; Tang, X.; Wang, H.; Fan, W.; Wang, G. Monitoring monthly surface water dynamics of Dongting Lake using Sentinel-1 data at $10 \mathrm{~m}$. PeerJ 2018, 6, e4992. [CrossRef] [PubMed]

14. Kang, S.; Hong, S.Y. Assessing seasonal and inter-annual variations of lake surface areas in Mongolia during 2000-2011 using minimum composite MODIS NDVI. PLoS ONE 2016, 11, e0151395. [CrossRef] [PubMed]

15. Li, Y.; Zhang, Q.; Yao, J.; Werner, A.D.; Li, X. Hydrodynamic and hydrological modeling of the Poyang Lake catchment system in China. J. Hydrol. Eng. 2013, 19, 607-616. [CrossRef]

16. Feyisa, G.L.; Meilby, H.; Fensholt, R. Automated Water Extraction Index: A new technique for surface water mapping using Landsat imagery. Remote Sens. Environ. 2014, 140, 23-35. [CrossRef]

17. Feng, L.; Hu, C.; Chen, X.; Cai, X.; Tian, L.; Gan, W. Assessment of inundation changes of Poyang Lake using MODIS observations between 2000 and 2010. Remote Sens. Environ. 2012, 121, 80-92. [CrossRef]

18. Plug, L.J.; Walls, C.; Scott, B.M. Tundra lake changes from 1978 to 2001 on the Tuktoyaktuk Peninsula, western Canadian Arctic. Geophys. Res. Lett. 2008, 35, 1-5. [CrossRef]

19. Zhang, S.; Gao, H. A novel algorithm for monitoring reservoirs under all-weather conditions at a high temporal resolution through passive microwave remote sensing. Geophys. Res. Lett. 2016, 43, 8052-8059. [CrossRef]

20. Belete, M.D.; Diekkrüger, B.; Roehrig, J. Characterization of Water Level Variability of the Main Ethiopian Rift Valley Lakes. Hydrology 2017, 3, 1. [CrossRef]

21. Yuan, Y.; Zeng, G.; Liang, J.; Huang, L.; Hua, S. Variation of water level in Dongting Lake over a 50-year period: Implications for the impacts of anthropogenic and climatic factors. J. Hydrol. 2015, 525, 450-456. [CrossRef]

22. Zohary, T.; Ostrovsky, I. Ecological impacts of excessive water level fluctuations in stratified freshwater lakes. Inland Waters 2011, 1, 47-59. [CrossRef]

23. Ding, X.W.; Li, X.F. Monitoring of the water-area variations of Lake Dongting in China with ENVISAT ASAR images. Int. J. Appl. Earth Obs. Geoinf. 2011, 13, 894-901. [CrossRef]

24. Du, T.; Xiong, L.H.; Yi, F.H.; Xiao, Y.; Song, Q.M. Relation of the Water Area of Dongting Lake to the Water Levels of Hydrological Stations Based on MODIS Images. Resour. Environ. Yangtze Basin 2012, 21, 756-765. (In Chinese)

25. Latt, Z.Z.; Wittenberg, H. Improving flood forecasting in a developing country: A comparative study of stepwise multiple linear regression and artificial neural network. Water Resour. Manag. 2014, 28, 2109-2128. [CrossRef]

(C) 2019 by the authors. Licensee MDPI, Basel, Switzerland. This article is an open access article distributed under the terms and conditions of the Creative Commons Attribution (CC BY) license (http://creativecommons.org/licenses/by/4.0/). 